\title{
Effect of Motivation, Communication Skill, and Work Environment on Employee Performance at PT. Jaya Anugrah Sukses Abadi
}

\author{
Santorianus Zebua ${ }^{1}$, Yandi Chandra ${ }^{2}$, Tommy Nasibta Simbolon ${ }^{3}$, \\ Hendra Jonathan Sibarani ${ }^{4}$ \\ 1,2,3,4Universitas Prima Indonesia, Indonesia. \\ Corresponding Author: Hendra Jonathan Sibarani
}

\begin{abstract}
The purpose of this study was to examine and analyze the effect of motivation, communication skill, and work environment on employee performance at PT. Jaya Anugrah Sukses Abadi. This study uses a quantitative approach. The population of this study is the entire number of employees at PT. Jaya Anugrah Sukses Abadi in October 2021 with 237 people. The sampling technique used is simple random sampling. Based on the calculations, the number of samples in this study was set at 149 employees. The analysis technique used in this research is multiple linear analysis technique. The results showed that there is no effect of motivation on employee performance at PT. Jaya Anugrah Sukses Abadi. There is effect of communication skill on employee performance at PT. Jaya Anugrah Sukses Abadi. There is effect of work environment on employee performance at PT. Jaya Anugrah Sukses Abadi. Simultaneously there are effect of motivation, communication skill, and work environment on employee performance at PT. Jaya Anugrah Sukses Abadi. The results of the regression calculation can be seen that the coefficient of determination ( $R$ square) obtained is 0.170 , this result means that $17 \%$ of employee performance can be explained by the variables of motivation, communication skill, and work environment, while the remaining $83 \%$ is explained by other variables that are not researched.
\end{abstract}

Keywords: Motivation, Communication Skill, Work Environment, Employee Performance

\section{INTRODUCTION}

Performance in the organization is the answer to the success or failure of the organizational goals that have been set. good performance is optimal performance, namely performance that is in accordance with organizational standards and supports the achievement of organizational goals. A good organization is an organization that seeks to improve the capabilities of its human resources, because this is a key factor to improve employee performance. To be able to improve the performance of employees for the company to survive in an unstable competitive business environment, it is necessary to pay attention to incentives in order to improve employee performance.

PT. Jaya Anugrah Sukses Abadi is a national company engaged in five-star supermarkets. In its activities in 2020, there was a decrease in employee performance as seen from the decline in sales and not achieving sales targets. In addition to the decline in sales that year, there was a lot of damage to the products sold because they were not well cared for and cared for.

Based on the data, sales in JanuaryJune 2021 did not reach the target at all, due to the short operating time of the company and the many reduced employees during 2021.

The decrease in employee performance can be caused by a lack of employee knowledge in understanding the tasks assigned by superiors, which still often 
occur, such as understanding the item code listed on the item. Mistakes like this often occur, especially for new employees. This allows misunderstandings between employees at work sites and results in consumers having to wait a long time to get the goods to be purchased. Therefore, consumers are often disappointed with the services provided so that they prefer to look for similar items elsewhere rather than having to wait a long time.

Decreased work motivation of employees if left unchecked will affect the performance of these employees which in turn will have an impact on the overall performance of the organization. Therefore, organizations really need employees who have high motivation at work because someone who has high motivation at work will get optimal work results, so that a job will be completed properly. the thing related to motivation is that they are not given BPS allowances and incentives for overtime are never given even though employees have given more time to work. This motivational problem also causes a high level of employee turnover.

From the data, it can be seen that every month there are employees who resign, the reason why employees leave often occurs because of erratic working hours because operating hours are always changing due to government regulations, besides that employees feel that the compensation provided is not sufficient for the needs of employees' lives.

Communication skills are very important for all company functions, because operational and management systems are driven by communication. Errors in communication due to the lack of good communication flow between divisions can cause errors in receiving information that have an impact on employee performance.

Based on the data, it can be seen that every month there are errors in work caused by poor communication. The message conveyed is not heard properly so that errors can occur in communication.
Providing a comfortable work environment will be able to provide satisfaction to employees for the work done and give a deep impression to employees which in the end employees will have good performance. The problem of the work environment felt by employees is that the canteen is not provided for employee breaks and the workplace is still in the process of being renovated so that employees are often disturbed by an uncomfortable atmosphere. Part of the warehouse that is very narrow so that goods are stacked this can endanger the safety of employees if the goods fall if they are arranged too high.

The purpose of this study was to examine and analyze the effect of motivation, communication skill, and work environment on employee performance at PT. Jaya Anugrah Sukses Abadi.

\section{LITERATURE REVIEW Motivation}

According to Taruh (2020:57), work motivation is something that creates enthusiasm or encouragement to work. Work motivation as a driver of work enthusiasm.

The indicators of work motivation according to Susanto (2017:49-50) are as follows:

1. Efforts to excel.

2. Efforts to develop yourself.

3. Passion to interact with the environment.

4. Passion to work together.

According to Taruh (2020:58), the strength and weakness of a worker's work motivation will determine the size of his or her achievements.

\section{Communication Skill}

According to Umam (2018:219), communication means notification, talk, conversation, exchange of thoughts or relationships.

According to Umam (2018:230), there are several things that need to be considered in creating effective communication. Based on this theory, 
Santorianus Zebua et.al. Effect of motivation, communication skill, and work environment on employee performance at PT. Jaya Anugrah Sukses Abadi.

researchers use it as an indicator of communication, namely:

\section{Know Your Speaking Partner}

By knowing our audience, we can choose the right words to convey information or our thoughts. That is, the language used must be in accordance with easy language.

\section{Be Understood by the Audience}

The information or ideas we convey may not be understood. So, by paying attention to our interlocutor, we will be able to adjust in communicating with him.

\section{Know the Goal}

The purpose of our communication greatly determines the way we convey information.

\section{Pay Attention to Context}

When communicating, context plays a very important role in clarifying the information conveyed.

\section{Learn about Culture}

The communicator must understand the culture of the interlocutor so that mutual understanding and adjustment of communication style can occur.

\section{Understand the Language}

By understanding other people's language, it means that we try to respect other people.

According to Haedar et al., (2018:114), good communication can be the right means in improving employee performance. Through communication, employees can ask their superiors for instructions regarding the implementation of work. Through communication, employees can also work together with each other.

\section{Work Environment}

According to Eroy et al. (2020:153), the work environment is everything that is around employees at work, both physical and non-physical that can affect employees while working.

These work environment indicators are taken from Siagian (2014:57-61), namely:

1. Workplace building.
2. Availability of adequate work equipment.

3. Availability of resting place to unwind.

4. Availability of places of religious worship.

5. Peer-level relationships.

6. Relationship between superiors and employees.

7. Cooperation between employees.

According to Sihaloho and Siregar

(2019:274), an unfavorable work environment will make employees have decreased performance and the time for achieving the tasks that have been given can run not according to the targets given so that the results of the work system that are applied become ineffective and efficient, on the contrary, the work environment that is Fun will have a good impact on themselves and the company so that employees get satisfaction in achieving their performance and the company also obtains the company goals it wants to achieve.

\section{Employee Performance}

According to Sudaryo et al. (2019:205), performance is a work achieved by a person in carrying out the tasks assigned to him and how much they can contribute to the organization.

Employee performance indicators in this study also use the theory of Sudaryo et al. (2019:206), namely:

1. Quality of work.

2. Quantity of work.

3. Working time.

4. Cooperation.

\section{RESEARCH METHODS}

This study uses a quantitative approach. According to Pandiangan (2015), quantitative approach is empirical research in which the data is in the form of something that can be calculated. The characteristics of quantitative research are as follows: quantitative research is closely related to numbers as research material, so that equipment such as calculators, computers, and others immediately become 
Santorianus Zebua et.al. Effect of motivation, communication skill, and work environment on employee performance at PT. Jaya Anugrah Sukses Abadi.

the main instruments of quantitative research (Pandiangan et al., 2021).

Population is a group or collection of objects or objects that will be generalized from the research results (Pandiangan, 2018). The population of this study is the entire number of employees at PT. Jaya Anugerah Sukses Abadi in October 2021 with 237 people. The sample is part of the population studied in a study and the results will be considered a reflection of the original population, but not the population itself (Pandiangan et al., 2018). The sampling technique used is simple random sampling. Based on the calculations, the number of samples in this study was set at 149 employees.

The analysis technique used in this research is multiple linear analysis technique. Multiple linear regression is a linear regression model involving more than one independent variable or predictor (Tobing et al., 2018). Multiple linear analysis technique consists of t test (partial), $F$ test (simultaneous), and coefficient of determination test (R2).

\section{RESULT}

\section{Descriptive Statistical Analysis}

The results of this analysis will explain the value of $\mathrm{n}$ as the research sample, the minimum value as the lowest value, the maximum value as the highest value, the mean as the average value and standard deviation.

The results of the descriptive statistical test explain the value of the four variables tested in the descriptive statistical analysis, namely motivation, communication skill, work environment, and employee performance.

Motivation with a value of 149 respondents, the mean value is 33.1477 with the smallest value of 26 and the largest value of 40 with a standard deviation of 3.18861 .

Communication skill with 149 respondents, the mean is 35.0336 with the smallest value of 25 and the largest value of 40 with a standard deviation of 2.38355 .

Work environment with a sample of 149 respondents with a mean of 59.5973 with the smallest value of 47 and the largest value of 69 units with a standard deviation of 4.71186 .

Employee performance with a value of 149 respondents, the mean of 33.9329 with the smallest value of 25 and the largest value of 40 units with a standard deviation of 3.18011 .

\section{t Test (Partial)}

Table 1. $t$ Test (Partial)

\begin{tabular}{|c|c|c|c|c|c|c|}
\hline \multicolumn{7}{|c|}{ Coefficients $^{\mathrm{a}}$} \\
\hline \multirow{2}{*}{\multicolumn{2}{|c|}{ Model }} & \multicolumn{2}{|c|}{ Unstandardized Coefficients } & \multirow{2}{*}{$\begin{array}{c}\text { Standardized Coefficients } \\
\text { Beta } \\
\end{array}$} & \multirow[t]{2}{*}{ t } & \multirow[t]{2}{*}{ Sig. } \\
\hline & & B & Std. Error & & & \\
\hline \multirow[t]{4}{*}{1} & (Constant) & 12.822 & 4.446 & & 2.884 & .005 \\
\hline & Motivation & -.020 & .072 & .022 & .280 & .779 \\
\hline & Communication Skill & .378 & .095 & .306 & 3.962 & .000 \\
\hline & Work Environment & .143 & .050 & .229 & 2.884 & .005 \\
\hline
\end{tabular}

The results showed that there is no effect of motivation on employee performance at PT. Jaya Anugerah Sukses Abadi. There is effect of communication skill on employee performance at PT. Jaya Anugerah Sukses Abadi. There is effect of work environment on employee performance at PT. Jaya Anugrah Sukses Abadi.

\section{F Test (Simultaneous)}

Simultaneously there are effect of motivation, communication skill, and work environment on employee performance at PT. Jaya Anugerah Sukses Abadi. 
Santorianus Zebua et.al. Effect of motivation, communication skill, and work environment on employee performance at PT. Jaya Anugrah Sukses Abadi.

Table 2. F Test (Simultaneous)

\begin{tabular}{|c|c|c|c|c|c|c|}
\hline \multicolumn{7}{|c|}{ ANOVA $^{\mathrm{a}}$} \\
\hline \multicolumn{2}{|c|}{ Model } & Sum of Squares & df & Mean Square & $\mathbf{F}$ & Sig. \\
\hline \multirow[t]{3}{*}{1} & Regression & 218.713 & 3 & 72.904 & 9.930 & $.000^{\mathrm{b}}$ \\
\hline & Residual & 1064.616 & 145 & 7.342 & & \\
\hline & Total & 1283.329 & 148 & & & \\
\hline \multicolumn{7}{|c|}{ a. Dependent Variable: Employee Performance } \\
\hline \multicolumn{7}{|c|}{ b. Predictors: (Constant), Motivation, Communication Skill, Work Environment } \\
\hline
\end{tabular}

\section{Coefficient of Determination Test (R2)}

Table 3. Coefficient of Determination Test (R2)

\begin{tabular}{|c|c|c|c|c|c|c|c|c|c|c|}
\hline \multicolumn{11}{|c|}{ Model Summaryb } \\
\hline \multirow[t]{2}{*}{ Model } & \multirow[t]{2}{*}{$\mathbf{R}$} & \multirow{2}{*}{$\begin{array}{c}\mathbf{R} \\
\text { Square }\end{array}$} & \multirow{2}{*}{$\begin{array}{l}\text { Adjusted } \\
\text { R Square }\end{array}$} & \multirow{2}{*}{$\begin{array}{l}\text { Std. Error } \\
\text { of the } \\
\text { Estimate }\end{array}$} & \multicolumn{5}{|c|}{ Change Statistics } & \multirow{2}{*}{$\begin{array}{l}\text { Durbin- } \\
\text { Watson }\end{array}$} \\
\hline & & & & & $\begin{array}{c}\mathbf{R} \\
\text { Square } \\
\text { Change }\end{array}$ & $\begin{array}{c}F \\
\text { Change }\end{array}$ & df1 & df2 & $\begin{array}{l}\text { Sig. F } \\
\text { Change }\end{array}$ & \\
\hline 1 & $.413^{\mathrm{a}}$ & .170 & .153 & 2.70965 & .170 & 9.930 & 3 & 145 & .000 & 1.334 \\
\hline \multicolumn{11}{|c|}{ a. Predictors: (Constant), Motivation, Communication Skill, Work Environment } \\
\hline
\end{tabular}

Source: Research Results (2021)

The results of the regression calculation can be seen that the coefficient of determination ( $\mathrm{R}$ square) obtained is 0.170 , this result means that $17 \%$ of employee performance can be explained by the variables of motivation, communication skill, and work environment, while the remaining $83 \%$ is explained by other variables that are not researched.

\section{CONCLUSION AND SUGGESTION}

The results showed that there is no effect of motivation on employee performance at PT. Jaya Anugerah Sukses Abadi. There is effect of communication skill on employee performance at PT. Jaya Anugerah Sukses Abadi. There is effect of work environment on employee performance at PT. Jaya Anugrah Sukses Abadi. Simultaneously there are effect of motivation, communication skill, and work environment on employee performance at PT. Jaya Anugerah Sukses Abadi. The results of the regression calculation can be seen that the coefficient of determination ( $R$ square) obtained is 0.170 , this result means that $17 \%$ of employee performance can be explained by the variables of motivation, communication skill, and work environment, while the remaining $83 \%$ is explained by other variables that are not researched.

Suggestions in this research are:
1. Companies should pay attention to motivation, because with good motivation, it is expected that employee performance will increase

2. Companies should always improve their communication skills and emotional intelligence in an effort to improve employee performance such as: providing opportunities for employees to take part in various trainings in training employees' communication skills and emotional intelligence, and attending informal education aimed at improving employee performance and building one-way and two-way communication.

3. The company should pay more attention to the work environment provided so that it is more conducive and feels more comfortable at work.

4. For further researchers, in order to further develop theories regarding variables that are suspected to have a relationship with employee performance such as: supervision, or discipline to be investigated in the future.

Acknowledgement: None

Conflict of Interest: None

Source of Funding: None 
Santorianus Zebua et.al. Effect of motivation, communication skill, and work environment on employee performance at PT. Jaya Anugrah Sukses Abadi.

\section{REFERENCES}

1. Eroy, Achmad Rozi El et al. (2020). 7 Steps to HRM 4.0. Cilegon: Runzune Sapta Konsultan.

2. Haedar, H., Sampetan, S., \& Suardi, A. (2018). Pengaruh Motivasi Dan Komunikasi Terhadap Kinerja Karyawan Pt. Finansia Multi Finance Cabang Palopo. Prosiding Seminar Nasional, 3(1), 2443-1109.

3. Pandiangan, Saut Maruli Tua. (2015). Analisis Lama Mencari Kerja Bagi Tenaga Kerja Terdidik di Kota Medan. Skripsi. Medan: Fakultas Ekonomi dan Bisnis, Program Studi Ekonomi Pembangunan, Universitas Sumatera Utara. https://www.academia.edu/52494724/Analis is_Lama_Mencari_Kerja_Bagi_Tenaga_Ker ja_Terdidik_di_Kota_Medan.

4. Pandiangan, Saut Maruli Tua. (2018). Analisis Faktor-faktor yang Mempengaruhi Penawaran Tenaga Kerja Lanjut Usia di Kota Medan. Tesis. Medan: Fakultas Ekonomi dan Bisnis, Program Studi Ilmu Ekonomi, Universitas Sumatera Utara. http://repositori.usu.ac.id/bitstream/handle/1 23456789/10033/167018013.pdf?sequence= 1\&isAllowed=y.

5. Pandiangan, Saut Maruli Tua, Rujiman, Rahmanta, Tanjung, Indra I., Darus, Muhammad Dhio, \& Ismawan, Agus. (2018). An Analysis on the Factors which Influence Offering the Elderly as Workers in Medan. IOSR Journal of Humanities and Social Science (IOSR-JHSS), 23(10), 76-79. DOI: 10.9790/0837-2310087679.

6. Pandiangan, Saut Maruli Tua, Resmawa, Ira Ningrum, Simanjuntak, Owen De Pinto, Sitompul, Pretty Naomi, \& Jefri, Riny. (2021). Effect of E-Satisfaction on Repurchase Intention in Shopee User Students. Budapest International Research and Critics Institute-Journal, 4(4), 7785-
7791.

DOI:

https://doi.org/10.33258/birci.v4i4.2697.

7. Siagian, Sondang P. (2014). Manajemen Sumber Daya Manusia. Jakarta: Bumi Aksara.

8. Sihaloho, R. D., \& Siregar, H. (2019). Pengaruh Lingkungan Kerja Terhadap Kinerja Karyawan Pada PT. Super Setia Sagita Medan. Jurnal Ilmiah Socio Secretum, 9(2), 273-281.

9. Sudaryo, Yoyo, et al. (2019). Manajemen Sumber Daya Manusia, Kompensasi Tidak Langsung dan Lingkungan Kerja Fisik. Yogyakarta: CV Andi Offset.

10. Sujarweni,V. W. (2021). Metodologi Penelitian Bisnis dan Ekonomi. Yogyakarta: Pustaka Baru Press.

11. Susanto, Y. (2017). Peran Kepemimpinan dalam Pengelolaan Koperasi. Yogyakarta: Deepublish.

12. Taruh, Ferdinatus. (2020). Motivasi Kerja. Yogyakarta: Deepublish.

13. Tobing, Murniati, Afifuddin, Sya'ad, Rahmanta, Huber, Sandra Rouli, Pandiangan, Saut Maruli Tua, \& Muda, Iskandar. (2018). An Analysis on the Factors Which Influence the Earnings of Micro and Small Business: Case at Blacksmith Metal Industry. Academic Journal of Economic Studies, 5(1), 17-23. https://www.ceeol.com/search/articledetail ?id=754945.

14. Umam, Khaerul. (2018). Perilaku Organisasi. Bandung: CV. Pustaka Setia.

How to cite this article: Santorianus Zebua, Yandi Chandra, Tommy Nasibta Simbolon et.al. Effect of motivation, communication skill, and work environment on employee performance at PT. Jaya Anugrah Sukses Abadi. International Journal of Research and Review. 2021; 8(12): 542-547. DOI: https://doi.org/10.52403/ijrr. 20211266 